\title{
The use of 16S rRNA gene metagenetic monitoring of refrigerated food products for understanding the kinetics of microbial subpopulations at different storage temperatures: the example of white pudding
}

\author{
Emilie Cauchie ${ }^{\mathrm{a}, *}$, Mathieu Gand ${ }^{\mathrm{a}}$, Gilles Kergourlay ${ }^{\mathrm{a}}$, Bernard Taminiau ${ }^{\mathrm{a}}$, Laurent Delhalle ${ }^{\mathrm{b}}$, \\ Nicolas Korsak ${ }^{a}$, Georges Daube ${ }^{\mathrm{a}}$ \\ a University of Liège, Faculty of Veterinary Medicine, Fundamental and Applied Research for Animal \& Health (FARAH), Food Science Departement - Food Microbiology, Quartier Vallée 2, \\ Avenue de Cureghem 10, B-4000 Liège, Belgium \\ ${ }^{\mathrm{b}}$ KeyFood platform, rue Auguste Piccard, 20, Maison de l'Industrie, 6040 Gosselies, Belgium
}

\section{A R T I C L E I N F O}

Article history:

Received 5 November 2015

Received in revised form 3 October 2016

Accepted 10 October 2016

Available online $\mathrm{xxxx}$

\section{Keywords:}

Microbial ecosystem

Jameson effect

Metagenetics

qPCR

Meat product

White pudding

\begin{abstract}
A B S T R A C T
In order to control food losses and wastage, monitoring the microbial diversity of food products, during processing and storage is important, as studies have highlighted the metabolic activities of some microorganisms which can lead to spoilage. Knowledge of this diversity can be greatly improved by using a metagenetic approach based on high throughput 16S rRNA gene sequencing, which enables a much higher resolution than culture-based methods. Moreover, the Jameson effect, a phenomenon described by Jameson in 1962, is often used to classify bacterial strains within an ecosystem. According to this, we have studied the bacterial microbiota of Belgian white pudding during storage at different temperatures using culture-dependent and independent methods. The product was inoculated with a mix of dominant strains previously isolated from this foodstuff at the end of its shelf life (Carnobacterium maltaromaticum, Lactobacillus fuchuensis, Lactobacillus graminis, Lactobacillus oligofermentans, Lactococcus lactis, Leuconostoc mesenteroides, Raoultella terrigena and Serratia sp.). Daily during 16 days, the absolute abundance of inoculated strain was monitored by combining total count on plate agar and metagenetic analysis. The results were confirmed by qPCR analysis. The growth of each species was modelled for each temperature conditions, representative of good or bad storage practices. These data allowed the bacterial strains subdivision into three classes based on criteria of growth parameters for the studied temperature: the "dominant", the "subdominant" and the "inhibited" bacterial species, according to their maximal concentration (Nmax, log CFU/g), growth rate ( $\mu$ max, $1 / \mathrm{h}$ ) and time to reach the stationary phase (TRSP, days). Thereby, depending on the storage conditions, these data have permitted to follow intrinsically the evolution of each strain on the bacterial ecosystem of Belgian white pudding. Interestingly, it has shown that the reliability of the Jameson effect can be discussed. For example, at $4{ }^{\circ} \mathrm{C}$ when Lactococcus lactis and Serratia sp. stopped growth at day 12 , at the same time Carnobacterium maltaromaticum reached its maximal concentration and entered its stationary phase. In opposition to this, it can be noticed that in the same condition, the "sub-dominant" organisms continued their growth independently of the "dominant" species behaviour. In this case, the Jameson effect was not illustrated. This pattern is described for all storage conditions with the same strain classifications. These results highlighted the importance of combining metagenetic analysis and classical methods, with modelling, to offer a new tool for studying the evolution of microorganisms present in perishable food within different environmental conditions.
\end{abstract}

(c) 2016 Elsevier B.V. All rights reserved.

\section{Introduction}

In past years, scientists who study the safety of highly perishable food products have focussed their work on the detection and the control of pathogenic microorganisms. However, Food Law (Regulation (EC)

* Corresponding author: Food Science Department, Faculty of Veterinary Medicine, University of Liège, Quartier Vallée 2, Avenue de Cureghem 10, B-4000 Liège, Belgium.

E-mail address: ecauchie@ulg.ac.be (E. Cauchie).
$\mathrm{N}^{\circ} 178 / 2002$ ) also integrates all products that are unfit for human consumption because of contamination, deterioration, decomposition or rotting into the definition of unsafe food. Around a third of all food produced for human consumption on Earth is lost or wasted. In Europe, the losses of initial meat production represent $20 \%$ and more than half of this occurs at animal production, slaughtering, processing and distribution steps (Food and Agriculture Organization, 2011; Kergourlay et al., 2015). These data highlight the importance of managing the microbiological quality of food products. Indeed, among the reasons for food 
loss and waste, spoilage by bacteria that contaminate the food matrix and are able to develop during transformation steps and storage is a major issue (Lipinski et al., 2013; Remenant et al., 2015).

For a clear and complete understanding of the mechanisms that lead to the spoilage of food products, classical microbiology is not sufficient. Fortunately, molecular technologies can elucidate the microbial communities, including the identification and quantification of culturable and non-culturable organisms, and can do so at a much higher resolution than was previously possible with culture-based methods (Kergourlay et al., 2015; Elizaquível et al., 2015). Many bacterial species putatively responsible for food spoilage have been reported, thanks to the development of high throughput sequencing methods, that allow for a more detailed and deeper description of bacterial species present in food (Benson et al., 2014; Chaillou et al., 2014; Delcenserie et al., 2014; Galimberti et al., 2015; Riquelme et al., 2015). These works are mainly limited to the description of the product's microbiota during its shelf life. However, spoilage is a complex process, resulting most often from incorrect storage temperatures and bacterial functions that are not fully understood. Spoilage is not only species and strain dependent, but also the result of interactions between strains. Few studies have described the evolution of a whole microbiota in a food matrix with consideration of the storage parameters (Ercolini et al., 2011; Nieminen et al., 2012).

The present study proposes to follow the evolution of the main bacterial species present in a famous Belgian meat product: the white pudding. For this, we inoculated a mix of strains previously isolated from aging tests on the same food matrix. The mix of inoculated strains has been studied in challenge tests at different storage temperatures, representative of good or bad practices. The growth of the added bacteria has been assessed daily at the same time by combining classical microbiology and 16S rRNA metagenetic analysis (Esposito and Kirschberg, 2014) with the goal of obtaining quantitative results for each strain and to study their respective kinetics. Quantitative PCR (qPCR) analysis targeted on corresponding bacterial genera was used in order to validate the metagenetic approach.

There are two objectives in this study: the first is to reinforce the importance of combining classical microbiology and metagenetics analysis, with modelling, as a new tool to follow the evolution of microorganisms present in perishable food within different environmental conditions. This approach can examine the potential for nextgeneration DNA sequencing methods to elucidate the detailed dynamics of microbial population during spoilage. To this end, a combination of metagenetics and traditional microbiological methods were used to quantify the microbiota of Belgian white pudding. The second is providing knowledge on the composition and dynamics of the emblematic bacterial species components of white pudding, and shown how it is affected by storage temperature.

\section{Material and methods}

\subsection{Food samples and selection of bacterial strains}

The strains used in this study were previously isolated from Belgian white puddings at the end of their use-by date, by one Belgian manufacturer (five batches analysed), after storage for a third of the storage period at $4{ }^{\circ} \mathrm{C}$ and the remaining time at $8{ }^{\circ} \mathrm{C}$ following the guidelines for implementing microbiological durability tests of chilled perishable and highly perishable foodstuffs (NF EN V01-003, 2010). The results of these first aging tests are not shown in this paper. Eight of the natural predominant strains isolated at the end of the shelf life, represented together more than $50 \%$ of the natural microbiota, were identified by sequencing of their 16S rRNA genes and used for the challenge-tests: Carnobacterium maltaromaticum, Lactobacillus fuchuensis, Lactobacillus graminis, Lactobacillus oligofermentans, Lactococcus lactis, Leuconostoc mesenteroides, Raoultella terrigena and Serratia sp. For this study, a short 16 days shelf life was evaluated for the Belgian white pudding.
Bacterial strains were stored at $-80{ }^{\circ} \mathrm{C}$ in nutrient broth with $30 \%$ glycerol as a cryoprotective agent. Before use, strains were transferred from the $-80{ }^{\circ} \mathrm{C}$ culture collection to Brain Heart Infusion (BHI) broth for C. maltaromaticum, R. terrigena and Serratia sp., and de Man, Rogosa and Sharpe (MRS) broth for Lb. fuchuensis, Lb. graminis, $L b$. oligofermentans, LC. lactis and Ln. mesenteroides for $48 \mathrm{~h}$ at $22^{\circ} \mathrm{C}$. The cultures were incubated overnight at $4{ }^{\circ} \mathrm{C}$ before inoculation.

\subsection{Challenge tests}

Thirty-three kilograms of white puddings (each $150 \mathrm{~g}$ ) were received from a Belgian manufacturer the day following their production and stored at $4{ }^{\circ} \mathrm{C}$ (composition: pork meat $64 \%$, milk, bread, onions, salt and spices. No sugar was added). The natural microbiota was considered as insignificant because these products were inoculated by a concentrate mix of eight bacterial species who dominate the initial indigenous microbiota. The surface products were inoculated by soaking for $2 \mathrm{~min}$ in a bath of sterile water containing a mix of the eight bacterial strains at the same concentrations with the goal of reaching an approximatively global concentration of $3 \log$ colony forming units (log CFU/g on the product), in duplicate $(\mathrm{n}=192)$. Non-inoculated control samples were soaking for the same time in a bath of sterile water only, in duplicate $(n=24)$. After a drying step of $20 \mathrm{~min}$ at $10^{\circ} \mathrm{C}$, white puddings were packed ( $300 \mathrm{~g}$ ) in a tray ( $\mathrm{PP} / \mathrm{EVOH} / \mathrm{PP})$ under modified atmosphere $\left(\mathrm{CO}_{2} 30 \% / \mathrm{N}_{2} 70 \%\right.$, Olympia $\mathrm{V} / \mathrm{G}$, Technovac, Italy) using packaging wrap (polyester $10 \mu \mathrm{m}$, homopolymer polypropylene $50 \mu \mathrm{m}$, NutriPack, France). According to the shelf life of the product, inoculated samples were stored at different temperatures, constant or dynamic: (i) for 16 days at $4{ }^{\circ} \mathrm{C}\left(4^{\circ} \mathrm{C}\right)$, (ii) for 16 days at $8{ }^{\circ} \mathrm{C}\left(8{ }^{\circ} \mathrm{C}\right)$, (iii) for 16 days at $12{ }^{\circ} \mathrm{C}\left(12{ }^{\circ} \mathrm{C}\right)$, (iv) for 4 days at $4{ }^{\circ} \mathrm{C}$ and for 12 days at $8{ }^{\circ} \mathrm{C}\left(4-8{ }^{\circ} \mathrm{C}\right),(v)$ for 4 days at $4{ }^{\circ} \mathrm{C}$, followed by a break of $4 \mathrm{~h}$ at $20^{\circ} \mathrm{C}$ than 12 days at $4{ }^{\circ} \mathrm{C}\left(4 / 20-4{ }^{\circ} \mathrm{C}\right)$, (vi) 4 days at $4{ }^{\circ} \mathrm{C}$, followed by a break of $4 \mathrm{~h}$ at $20^{\circ} \mathrm{C}$ then 12 days at $8{ }^{\circ} \mathrm{C}\left(4 / 20-8{ }^{\circ} \mathrm{C}\right)$. Control samples were only stored at the first day and at day 16 .

\subsection{Incubation and enumeration by conventional microbiological method}

Each day during the 16-day storage period except on day 2, $25 \mathrm{~g}$ of product were put into a Stomacher bag with a mesh screen liner (80 $\mu \mathrm{m}$ pore size) (bioMérieux, Basingstoke, England, ref 80015) under aseptic conditions. Physiological water $(225 \mathrm{~mL})$ was automatically added to each bag (Dilumat, Biomerieux, Belgium) and the samples were homogenised for $2 \mathrm{~min}$ in a Stomacher (Bagmixer, Interscience, France). From this primary suspension, decimal dilutions in peptone water ( $1 \mathrm{~g} / \mathrm{L}$ peptone, $8.5 \mathrm{~g} / \mathrm{L}$ sodium chloride) were prepared for microbiological analysis and $0.1 \mathrm{~mL}$ aliquots of the appropriate dilutions were plated onto media for each analysis in duplicate (Spiral plater, DW Scientific, England). A total count was made on Plate Count Agar (PCA) at $22{ }^{\circ} \mathrm{C}$ for $48 \mathrm{~h}$ for the psychrotrophic aerobic plate count, using the modified method specified by the International Organization for Standardization [ISO (2013, ISO 4833-2)]. Graphs were plotted with each of the day time points over the 16-day storage period $(\mathrm{n}=192)$. Non-inoculated products were only analysed at day 1 and day $16(\mathrm{n}=24)$.

\subsection{Total DNA extraction}

Bacterial DNA was directly extracted from each primary suspension, which had been stored at $-80{ }^{\circ} \mathrm{C}$, using the DNeasy Blood \& Tissue DNA Extraction kit (Qiagen, Venlo, Netherlands), following the manufacturer's recommendations. The resulting DNA extracts were eluted in DNAse/RNAse free water and their concentrations and purity were evaluated by means of optical density using the NanoDrop ND1000 spectrophotometer (Isogen, St-Pieters-Leeuw, Belgium). The quality and quantity of the products were confirmed by Picogreen 


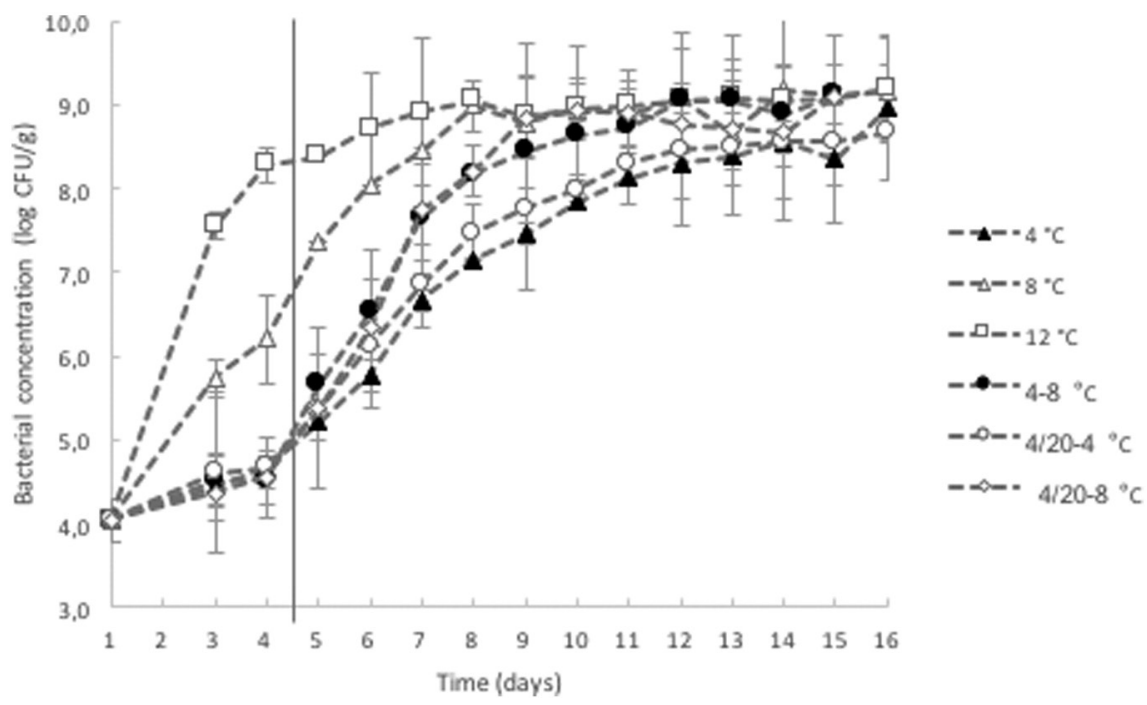

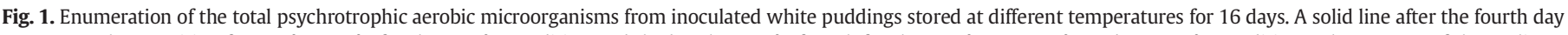

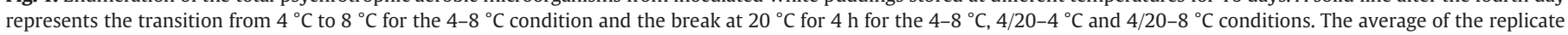
plating is plotted, with the standard deviation indicated by the whiskers.

double-stranded DNA (dsDNA) quantitation assay (Isogen, St-PietersLeeuw, Belgium). DNA samples were stored at $-20{ }^{\circ} \mathrm{C}$ until use for 16S rRNA amplicon pyrosequencing and qPCR analysis.

\subsection{Bacterial $16 \mathrm{~S}$ rRNA gene amplification and barcoded pyrosequencing}

16S rRNA PCR libraries targeting the V1-V3 hypervariable region were generated. Primers E9-29 and E514-430 (Brosius et al., 1981), specific for bacteria, were selected for their theoretical ability to generate the lowest amplification bias relative to amplification capability among the various bacterial phyla (Wang and Qian, 2009). The oligonucleotide design included 454 Life Sciences A or B sequencing titanium adapters (Roche Diagnostics, Vilvoorde, Belgium) and multiplex identifiers (MIDs) fused to the $5^{\prime}$ end of each primer. The amplification mix contained 5 units (U) of FastStart high fidelity polymerase (Roche Diagnostics, Vilvoorde, Belgium), $1 \times$ enzyme reaction buffer, $200 \mu \mathrm{M}$ deoxynucleotide triphosphates (dNTPs) (Eurogentec, Liège, Belgium), $0.2 \mu \mathrm{M}$ of each primer and $100 \mathrm{ng}$ of genomic DNA in a final volume of $100 \mu \mathrm{L}$. Thermocycling conditions consisted of a denaturation step of 15 min at $94{ }^{\circ} \mathrm{C}$, followed by 25 cycles of $40 \mathrm{~s}$ at $94{ }^{\circ} \mathrm{C}, 40 \mathrm{~s}$ at $56^{\circ} \mathrm{C}$, and $1 \mathrm{~min}$ at $72{ }^{\circ} \mathrm{C}$, with a final elongation step of $7 \mathrm{~min}$ at $72{ }^{\circ} \mathrm{C}$. These amplifications were performed on an EP Mastercycler Gradient System apparatus (Eppendorf, Hamburg, Germany). The PCR products were run on $1 \%$ agarose gel electrophoresis and the DNA fragments were plugged out and purified using a Wizard SV PCR purification kit
(Promega Benelux, Leiden, Netherlands). The quality and quantity of the products were assessed by Picogreen dsDNA quantitation assay (Isogen, St-Pieters-Leeuw, Belgium). Equal amounts of each of the PCR products were pooled and subsequently amplified by emulsion PCR. Pyrosequencing was performed with the Illumina sequencer (Illumina, Eindhoven, Netherlands) $(2 \times 300 \mathrm{bp})$. A mean 19,581 of reads per day were analysed for all temperature conditions.

\subsection{Bioinformatics and data analysis}

The 16S rRNA gene sequence reads were processed with MOTHUR (Pothakos et al., 2014; Schloss et al., 2009). The quality of all sequence reads were denoised using the Pyronoise algorithm implemented in MOTHUR. The sequences were checked for the presence of chimeric amplification using ChimeraSlayer (developed by the Broad Institute, http://microbiomeutil.sourceforge.net/\#A_CS). The obtained reads sets were compared to a reference dataset of aligned sequences of the corresponding region derived from the SILVA database of full-length rRNA gene sequences (http://www.arb-silva.de/) implemented in MOTHUR (Pothakos et al., 2014). The final reads were clustered into operational taxonomic units (OTUs) using the nearest neighbour algorithm using MOTHUR with a 0.03 distance unit cut off. A taxonomic identity was attributed to each OTU by comparison to the SILVA database using an $80 \%$ homogeneity cut off. As MOTHUR is not dedicated to the taxonomic assignment beyond the genus level, all unique sequences for each OTU

Table 1

Primers and probes designed for the qPCR tests.

\begin{tabular}{|c|c|c|c|}
\hline Target bacterial genus & Target gene & Primers & Sequence \\
\hline \multirow[t]{3}{*}{ Lactobacillus } & \multirow[t]{3}{*}{ Tuf } & Lactobacillus-Tuf-F2 & 5'-GCYCACGTWGAATAYGAAAC-3' \\
\hline & & Lactobacillus-Tuf-R2 & 5'-CGDACTTCCATTTCAACYAAGTC-3' \\
\hline & & Lactobacillus-Tuf-FAM1 & 5'-TGTGGCATWGGRCCATCAGTTGC-3' \\
\hline \multirow[t]{3}{*}{ Lactococcus } & \multirow[t]{3}{*}{ RecA } & Lactococcus-RecA-F2 & 5'-GCCGAAATYGATGGYGAAAT-3' \\
\hline & & Lactococcus-RecA-R2 & 5'-CAACTTTTTCACGCAATTGGTTG-3' \\
\hline & & Lactococcus-RecA-FAM4 & 5'-TGATGTCWCAAGCYATGCGTAAAC-3' \\
\hline \multirow{3}{*}{ Leuconostoc } & \multirow{3}{*}{ Fus } & Leuconostoc-Fus-F1 & 5'-TTCTTGTTCCATGAAATCCATTTG-3' \\
\hline & & Leuconostoc-Fus-R1 & 5'-GAATACCCACTAGAWCGTACAC-3' \\
\hline & & Leuconostoc-Fus-FAM1 & 5'-TGTGTTTCACCAATTTTGTGAATTTTACC-3' \\
\hline \multirow{3}{*}{ Carnobacterium } & \multirow{3}{*}{ rрoA } & Carnobacterium-rpoA-F1 & 5'-ATTGGYGTATTACCAGTCGA-3' \\
\hline & & Carnobacterium-rpoA-R1 & 5'-AACCATCTGCCCATACATC-3' \\
\hline & & Carnobacterium-rpoA-FAM1 & 5'-CGATTTACACCCCAGTTAGTCGT-3' \\
\hline
\end{tabular}

Primers and probes designed for the qPCR tests allowing for the relative proportion of genera mainly present in Belgian white pudding to be estimated. 
Table 2

Metagenetics results for constant temperature condition.

\begin{tabular}{|c|c|c|c|c|c|c|c|c|c|c|c|c|c|c|c|}
\hline \multirow[b]{2}{*}{ Bacterial strains/temperature } & \multicolumn{15}{|l|}{ Days } \\
\hline & 1 & 3 & 4 & 5 & 6 & 7 & 8 & 9 & 10 & 11 & 12 & 13 & 14 & 15 & 16 \\
\hline \multicolumn{16}{|l|}{$4{ }^{\circ} \mathrm{C}$} \\
\hline C. maltaromaticum & 1.1 & 3.2 & 4.5 & 11.5 & 25.8 & 70.5 & 86.8 & 96.7 & 96.4 & 93.9 & 90.7 & 76.7 & 65.8 & 50.4 & 42.1 \\
\hline Lc. lactis & 0.3 & 0.2 & 0.1 & 0.4 & 1.2 & 0.2 & 0.2 & 0.0 & 0.0 & 0.0 & 0.0 & 0.1 & 0.0 & 0.0 & 0.0 \\
\hline Ln. mesenteroides & 0.1 & 0.3 & 0.0 & 0.3 & 0.5 & 0.6 & 1.3 & 0.3 & 0.0 & 0.6 & 0.7 & 1.3 & 4.2 & 4.6 & 12.5 \\
\hline Lb. graminis & 0.2 & 0.4 & 1.3 & 0.5 & 0.8 & 1.5 & 1.8 & 0.2 & 0.0 & 0.8 & 0.7 & 1.9 & 2.7 & 3.8 & 4.3 \\
\hline Serratia sp. & 0.2 & 0.2 & 0.7 & 0.6 & 0.8 & 0.8 & 0.7 & 0.2 & 0.1 & 0.2 & 0.1 & 0.1 & 0.6 & 0.2 & 0.5 \\
\hline Lb. fuchuensis & 0.2 & 0.4 & 0.6 & 0.6 & 1.5 & 1.9 & 3.1 & 0.4 & 1.1 & 2.8 & 4.2 & 13.6 & 18.1 & 35.8 & 32.3 \\
\hline Other strains & 97.9 & 95.1 & 92.8 & 86.2 & 69.3 & 24.5 & 6.0 & 2.0 & 2.5 & 1.7 & 3.6 & 6.3 & 8.6 & 5.1 & 8.2 \\
\hline \multicolumn{16}{|l|}{$8{ }^{\circ} \mathrm{C}$} \\
\hline C. maltaromaticum & 1.1 & 33.8 & 60.4 & 69.8 & 75.1 & 48.8 & 43.0 & 18.7 & 8.4 & 14.0 & 7.0 & 6.7 & 8.2 & 8.3 & 3.4 \\
\hline Lb. fuchuensis & 0.3 & 2.4 & 6.5 & 4.4 & 4.2 & 14.8 & 18.3 & 36.3 & 16.2 & 30.7 & 10.1 & 18.2 & 14.5 & 11.9 & 16.6 \\
\hline Lb. graminis & 0.1 & 1.7 & 2.4 & 5.2 & 4.3 & 9.8 & 15.3 & 10.8 & 23.1 & 17.4 & 50.4 & 45.6 & 45.7 & 39.2 & 53.7 \\
\hline Ln. mesenteroides & 0.2 & 2.3 & 5.9 & 3.5 & 2.6 & 4.3 & 3.0 & 3.1 & 0.5 & 1.7 & 2.4 & 3.0 & 2.7 & 4.1 & 2.3 \\
\hline Lc. Lactis & 0.2 & 1.8 & 3.1 & 4.3 & 4.3 & 5.0 & 0.7 & 0.2 & 0.7 & 1.0 & 0.6 & 0.9 & 0.9 & 0.7 & 1.2 \\
\hline Serratia sp. & 0.2 & 1.2 & 2.6 & 5.4 & 3.8 & 8.0 & 8.5 & 19.1 & 26.1 & 23.0 & 15.7 & 14.9 & 15.7 & 26.2 & 12.4 \\
\hline Other strains & 97.9 & 56.8 & 19.1 & 7.4 & 5.7 & 9.3 & 11.2 & 11.9 & 25.1 & 12.2 & 13.8 & 10.6 & 12.4 & 9.6 & 10.4 \\
\hline \multicolumn{16}{|l|}{$12{ }^{\circ} \mathrm{C}$} \\
\hline C. maltaromaticum & 1.1 & 8.0 & 2.7 & 0.8 & 0.7 & 0.7 & 0.8 & 1.1 & 0.8 & 0.8 & 1.0 & 0.4 & 0.6 & 0.5 & 0.6 \\
\hline Lb. fuchuensis & 0.3 & 83.8 & 92.0 & 92.5 & 88.5 & 83.1 & 79.5 & 65.6 & 61.7 & 62.7 & 43.0 & 53.1 & 54.1 & 46.6 & 43.8 \\
\hline Lb. graminis & 0.1 & 1.2 & 0.8 & 0.8 & 2.3 & 6.4 & 5.4 & 12.0 & 11.5 & 12.6 & 33.5 & 24.8 & 19.8 & 33.5 & 31.4 \\
\hline Ln. mesenteroides & 0.2 & 1.3 & 0.4 & 0.9 & 0.8 & 1.2 & 0.6 & 1.1 & 0.0 & 2.0 & 0.9 & 1.4 & 1.8 & 1.4 & 1.6 \\
\hline Lc. Lactis & 0.2 & 1.7 & 0.6 & 0.1 & 0.5 & 0.2 & 0.2 & 0.1 & 0.1 & 0.1 & 0.2 & 0.3 & 0.2 & 0.0 & 0.1 \\
\hline Serratia sp. & 0.2 & 0.7 & 0.3 & 0.4 & 2.9 & 4.5 & 3.7 & 9.5 & 14.2 & 17.1 & 10.6 & 13.6 & 14.7 & 11.7 & 12.7 \\
\hline Other strains & 97.9 & 3.4 & 3.1 & 4.3 & 4.4 & 4.0 & 9.8 & 10.5 & 11.6 & 4.7 & 10.8 & 6.4 & 8.8 & 6.4 & 9.8 \\
\hline
\end{tabular}

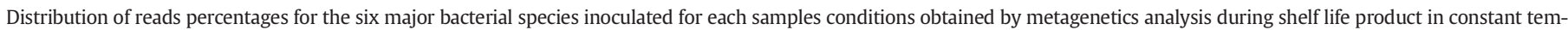
perature. Others strains represented the natural microbiota of white pudding.

were compared to the SILVA dataset 111 using a BLASTN algorithm (Delcenserie et al., 2014; Pothakos et al., 2014). For each OTU, a consensus detailed taxonomic identification was given based upon the identity ( $<1 \%$ mismatch with the aligned sequence) and the metadata associated with the best hit (validated bacterial species or not) (Delcenserie et al., 2014; Pothakos et al., 2014).

\subsection{Estimate abundance results}

The PCA results of the microflora at $22{ }^{\circ} \mathrm{C}$ (Fig. 1, expressed in log $\mathrm{CFU} / \mathrm{g}$ ) and the relative proportions of strains given by metagenetics (Tables 2 and 3, expressed in \%) were combined in order to obtain estimate counts for the strains (in $\log \mathrm{CFU} / \mathrm{g}$ ). For this, relative abundance of

Table 3

Metagenetics results for dynamic temperature condition.

\begin{tabular}{|c|c|c|c|c|c|c|c|c|c|c|c|c|c|c|}
\hline \multirow[b]{2}{*}{ Bacterial strains/temperature } & \multicolumn{14}{|l|}{ Days } \\
\hline & 1 & 3 & 4 & 5 & 6 & 7 & 8 & 9 & 10 & 11 & 12 & 13 & 14 & 15 \\
\hline \multicolumn{15}{|l|}{$4-8{ }^{\circ} \mathrm{C}$} \\
\hline C. maltaromaticum & 1.1 & 8.7 & 2.6 & 50.4 & 49.8 & 89.5 & 86.3 & 72.0 & 48.5 & 27.0 & 14.6 & 15.2 & 7.3 & 11.9 \\
\hline Lc. lactis & 0.3 & 20.2 & 10.8 & 4.1 & 16.0 & 0.3 & 0.4 & 0.4 & 1.0 & 2.6 & 2.3 & 2.7 & 2.4 & 3.6 \\
\hline Ln. mesenteroides & 0.1 & 1.5 & 0.5 & 1.1 & 4.8 & 1.2 & 2.5 & 3.1 & 6.8 & 15.7 & 46.1 & 49.4 & 59.6 & 41.2 \\
\hline Lb. graminis & 0.2 & 2.3 & 0.2 & 2.0 & 2.5 & 1.3 & 2.2 & 3.0 & 0.0 & 4.4 & 3.9 & 4.1 & 1.3 & 4.9 \\
\hline Serratia sp. & 0.2 & 1.1 & 0.4 & 1.3 & 2.8 & 0.8 & 0.7 & 0.5 & 1.0 & 0.6 & 0.8 & 1.2 & 0.1 & 1.2 \\
\hline Lb. fuchuensis & 0.2 & 0.9 & 0.3 & 1.7 & 7.3 & 2.7 & 4.7 & 11.3 & 26.4 & 36.9 & 23.4 & 17.7 & 11.3 & 27.0 \\
\hline Other strains & 97.9 & 65.3 & 85.1 & 39.4 & 16.9 & 4.1 & 3.3 & 9.8 & 16.3 & 12.7 & 8.9 & 9.8 & 18.0 & 10.2 \\
\hline \multicolumn{15}{|l|}{$4 / 20-4{ }^{\circ} \mathrm{C}$} \\
\hline C. maltaromaticum & 1.1 & 3.9 & 2.8 & 32.7 & 29.8 & 69.8 & 92.4 & 80.5 & 92.7 & 83.7 & 68.5 & 57.9 & 35.1 & 29.1 \\
\hline Lc. lactis & 0.3 & 1.0 & 2.3 & 16.9 & 19.9 & 0.0 & 0.0 & 0.0 & 0.0 & 0.1 & 0.1 & 0.0 & 0.1 & 0.1 \\
\hline Ln. mesenteroides & 0.1 & 0.3 & 0.3 & 0.7 & 4.8 & 2.5 & 1.1 & 4.2 & 0.3 & 0.8 & 2.4 & 4.8 & 10.4 & 12.3 \\
\hline Lb. graminis & 0.2 & 0.1 & 0.6 & 2.4 & 3.9 & 1.8 & 0.8 & 2.2 & 0.0 & 1.8 & 2.0 & 4.6 & 4.7 & 4.8 \\
\hline Serratia sp. & 0.2 & 0.4 & 0.3 & 1.7 & 2.4 & 1.7 & 0.5 & 0.4 & 0.2 & 0.1 & $0 / 3$ & 0.2 & 0.7 & 0.4 \\
\hline Lb. fuchuensis & 0.2 & 0.2 & 0.3 & 1.4 & 5.6 & 3.9 & 2.2 & 8.8 & 2.9 & 5.2 & 15.1 & 25.0 & 37.7 & 39.6 \\
\hline Other strains & 97.9 & 94.1 & 93.5 & 44.4 & 33.5 & 20.4 & 3.1 & 3.9 & 3.8 & 8.4 & 11.6 & 7.5 & 11.2 & 13.6 \\
\hline \multicolumn{15}{|l|}{$4 / 20-8{ }^{\circ} \mathrm{C}$} \\
\hline C. maltaromaticum & 1.1 & 2.3 & 3.0 & 35.5 & 38.4 & 88.0 & 89.9 & 56.6 & 36.7 & 24.2 & 12.0 & 13.0 & 12.6 & 9.2 \\
\hline Lc. lactis & 0.3 & 1.2 & 0.8 & 24.4 & 21.3 & 0.8 & 0.2 & 2.5 & 9.1 & 7.4 & 12.3 & 11.6 & 21.1 & 8.2 \\
\hline Ln. mesenteroides & 0.1 & 0.1 & 0.2 & 1.7 & 3.1 & 1.6 & 1.5 & 6.4 & 5.2 & 20.7 & 39.3 & 29.6 & 29.0 & 46.4 \\
\hline Lb. graminis & 0.2 & 0.4 & 0.9 & 2.3 & 2.5 & 1.4 & 1.5 & 3.9 & 0.0 & 5.6 & 4.4 & 4.0 & 4.1 & 5.2 \\
\hline Serratia sp. & 0.2 & 0.4 & 0.3 & 1.1 & 2.5 & 0.8 & 0.3 & 0.5 & 3.8 & 1.1 & 1.1 & 2.9 & 3.1 & 0.7 \\
\hline Lb. fuchuensis & 0.2 & 0.2 & 0.6 & 1.6 & 4.2 & 1.6 & 2.3 & 20.6 & 29.7 & 30.3 & 16.2 & 25.1 & 20.7 & 17.5 \\
\hline Other strains & 97.6 & 95.5 & 94.1 & 33.4 & 28.0 & 5.8 & 4.2 & 9.5 & 15.6 & 10.7 & 14.8 & 13.8 & 9.5 & 12.8 \\
\hline
\end{tabular}

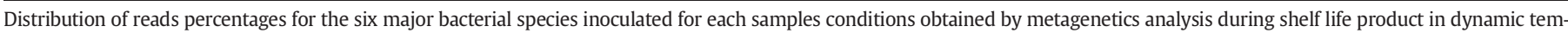
perature. Others strains represented the natural microbiota of white pudding. 
bacteria obtained by metagenetic results were reported over the PCA real value (Eq. 1). Indeed, thanks to the plate counts estimates, the proportions of the bacterial populations were transformed into concentrations. These results were used for statistical and graphical analysis.

$C_{\text {bacterial strain }}=\left(C_{\text {total flora }} \times N_{\text {reads of bacterial strain }}\right) / 100$

Eq. 1

Where $C_{\text {bacterial strain }}$ is the estimated abundance concentration in the sample ( $\log \mathrm{CFU} / \mathrm{g})$.

$C_{\text {total flora }}$ is the bacterial concentration per samples in the PCA analysis ( $\log \mathrm{CFU} / \mathrm{g})$.

$N_{\text {reads of bacterial strain }}$ is the number of reads for the bacterial strain per sample in the metagenetic analysis (expressed in \% of the total number reads in the sample).

\section{8. qPCR analysis}

The primers described in Table 1 were used for real-time PCR assay analysis using the Lightcycler 480 system (Roche, Basel, Switzerland). The real-time PCR reaction mixtures were combined in a $12 \mu \mathrm{L}$ final volume containing $6 \mu \mathrm{L}$ of LC480 probe master mix (Roche, Basel, Switzerland), $2 \mu \mathrm{L}$ of template DNA (at $5 \mathrm{ng} / \mu \mathrm{L}), 0.25 \mu \mathrm{L}$ of primer pairs $(10 \mu \mathrm{M}$ each), $0.125 \mu \mathrm{L}$ of Taqman probe $(10 \mu \mathrm{M})$. The reaction conditions included the initiation step off $10 \mathrm{~min}$ at $95^{\circ} \mathrm{C}$, followed by 40 cycles of $15 \mathrm{~s}$ at $95^{\circ} \mathrm{C}$ and $1 \mathrm{~min}$ at $60^{\circ} \mathrm{C}$. The real-time system is supplied with the Lightcycler 480 Software version 1.5 using unique Roche algorithms for highly accurate and robust automated data analysis. Serial dilutions ( $10^{6}$ to 1 copy numbers) of bacterial DNA were used for determining reference curves. The arithmetic mean of Cycle Threshold (CT) of the three repetitions was used in order to estimate the load of targeted bacterial populations present in the samples.

\subsection{Statistical analysis}

Using R software, the Analysis of Covariance (ANCOVA) test was used to evaluate if bacterial concentrations ( $\log \mathrm{CFU} / \mathrm{g}$ ) are equal across levels of a categorical independent variable (temperature conditions or microbial count method). With relation to temperature conditions, ANCOVA tests were realised using the bacterial growth data (from day 1 to day 16) and the bacterial growth during the exponential phase data (from day 4 to day 8 ). All tests were considered as significant for a p-value of $<0.05$.

\section{Results}

\subsection{Bacterial evolution by classical microbiological analysis}

Fig. 1 shows the PCA results from inoculated Belgian white puddings at different temperatures. The bacterial population showed different dynamic changes depending on conditions of storage and stabilised between 8.5 and $9.2 \log \mathrm{CFU} / \mathrm{g}$. For the non-inoculated products, results were respectively inferior to $3 \mathrm{log} \mathrm{CFU} / \mathrm{g}$ and the same as inoculated products at day 16 .

As expected, the storage temperature had a strong impact on the bacterial evolutions. A high storage temperature is correlated to a high growth rate during exponential phase and a stationary phase more rapidly reached. While the break at $20^{\circ} \mathrm{C}$ for $4 \mathrm{~h}$ doesn't seem to have a significant effect on the evolution of the culturable microflora, the transition from $4{ }^{\circ} \mathrm{C}$ to $8{ }^{\circ} \mathrm{C}$ stimulated the growth of the microorganisms. It would be interesting to intrinsically study the effect of temperature conditions on the behaviour of each strain inside the ecosystem.

\subsection{Relative abundance results obtained by metagenetics analysis}

The distribution of reads percentages for the eight major bacterial species for each samples $(n=768)$ in constant temperature shows
Table 4

Growth parameters of bacterial strains in inoculated white puddings under constant storage conditions.

\begin{tabular}{lllll}
\hline & Nmax & TRSP & $\mu \max$ & Class \\
\hline $4{ }^{\circ} \mathrm{C}$ & & & & \\
C. maltaromaticum & 8.6 & 12 & 0.07 & $\mathrm{D}$ \\
Lb. fuchuensis & 8.5 & 16 & 0.05 & $\mathrm{~S}$ \\
Lb. graminis & 7.6 & 16 & 0.03 & $\mathrm{~S}$ \\
Ln. mesenteroides & 8.1 & 16 & 0.03 & $\mathrm{~S}$ \\
Lc. Lactis & 4.9 & 12 & 0.05 & $\mathrm{I}$ \\
Serratia sp. & 6.7 & 12 & 0.04 & $\mathrm{I}$ \\
$8{ }^{\circ} \mathrm{C}$ & & & & \\
C. maltaromaticum & 8.1 & 8 & & \\
Lc. Lactis & 8.4 & 10 & 0.10 & $\mathrm{D}$ \\
Lb. fuchuensis & 8.3 & 10 & 0.09 & $\mathrm{~S}$ \\
Ln. mesenteroides & 8.9 & 10 & 0.10 & $\mathrm{~S}$ \\
Lb. graminis & 7.6 & 8 & 0.08 & $\mathrm{~S}$ \\
Serratia sp. & 6.7 & 8 & 0.10 & $\mathrm{I}$ \\
12 ${ }^{\circ} \mathrm{C}$ & & & & \\
Lc. Lactis & & 4 & & \\
Lb. fuchuensis & 8.9 & 11 & 0.25 & $\mathrm{D}$ \\
Ln. mesenteroides & 8.3 & 11 & 0.14 & $\mathrm{~S}$ \\
C. maltaromaticum & 8.7 & 4 & 0.10 & $\mathrm{~S}$ \\
Lb. graminis & 7.0 & 4 & 0.10 & $\mathrm{I}$ \\
Serratia sp. & 7.4 & 4 & 0.11 & $\mathrm{I}$ \\
\hline Baterial concentration & 6.0 & & 0.12 & $\mathrm{I}$ \\
\hline
\end{tabular}

Bacterial concentration at day 16 (Nmax, log $\mathrm{CFU} / \mathrm{g})$, time to reach the stationary phase (TRSP, days) and maximal bacterial growth rate ( $\mu$ max, $1 / \mathrm{h}$ ). Bacterial strains were subdivided into three categorical classes: D (“dominant"), S ("subdominant"), I ("inhibited").

that at day 7 the mix reach more than $70 \%$ of total reads in samples for $4{ }^{\circ} \mathrm{C}$. The same percentage is attained at day 3 both for $8{ }^{\circ} \mathrm{C}$ and $12{ }^{\circ} \mathrm{C}$. The major bacterial species concerned C. maltaromaticum at $4{ }^{\circ} \mathrm{C}$ and Lc. lactis at $12{ }^{\circ} \mathrm{C}$. All inoculated samples reached more than $90 \%$ at the end of shelf-life product (Table 2) and the natural microbiota of the white pudding seems to become minor in contrast to the inoculated

\section{Table 5}

Comparison of bacterial strains in inoculated white puddings subject to storage conditions with changes of temperature, according to the time taken to reach a $7 \mathrm{log} \mathrm{CFU} / \mathrm{g}$ threshold and ANCOVA-test based on the global growth and the growth rate during exponential phase.

\begin{tabular}{|c|c|c|c|c|}
\hline \multirow[t]{2}{*}{ Bacterial strains } & \multicolumn{2}{|c|}{$\begin{array}{l}7 \log \text { CFU/g } \\
\text { threshold (days) }\end{array}$} & \multicolumn{2}{|l|}{ ANCOVA-test } \\
\hline & $4{ }^{\circ} \mathrm{C}$ & $4-8{ }^{\circ} \mathrm{C}$ & $\begin{array}{l}\text { Global } \\
\text { growth }\end{array}$ & $\begin{array}{l}\text { Growth rate during } \\
\text { exponential phase }\end{array}$ \\
\hline \multicolumn{5}{|l|}{ a. } \\
\hline C. maltaromaticum & 8 & 7 & $\varnothing$ & $4-8>4^{* *}$ \\
\hline Lc. lactis & - & 11 & $4-8>4^{* * *}$ & $4-8>4^{* *}$ \\
\hline Lb. fuchuensis & 12 & 8 & $4-8>4^{* *}$ & $4-8>4^{* *}$ \\
\hline Lb. graminis & 14 & 9 & $4-8>4^{* *}$ & $4-8>4^{* *}$ \\
\hline Ln. mesenteroides & 14 & 9 & $4-8>4^{* * *}$ & $4-8>4^{* * *}$ \\
\hline Serratia sp. & - & 12 & $4-8>4^{* *}$ & $4-8>4^{* *}$ \\
\hline \multicolumn{5}{|l|}{ b. } \\
\hline C. maltaromaticum & 8 & 7 & $\varnothing$ & $\varnothing$ \\
\hline Lc. lactis & - & - & $4 / 20-4>4^{*}$ & - \\
\hline Lb. fuchuensis & 12 & 11 & $4 / 20-4>4^{*}$ & $\varnothing$ \\
\hline Lb. graminis & 14 & 12 & $4 / 20-4>4^{*}$ & $\varnothing$ \\
\hline Ln. mesenteroides & 14 & 12 & $4 / 20-4>4^{* *}$ & $4 / 20-4>4^{*}$ \\
\hline Serratia sp. & - & - & $4 / 20-4>4^{*}$ & $\varnothing$ \\
\hline \multicolumn{5}{|l|}{ c. } \\
\hline C. maltaromaticum & 7 & 7 & $\varnothing$ & $\varnothing$ \\
\hline Lc. lactis & 11 & 9 & $\varnothing$ & $\varnothing$ \\
\hline Lb. fuchuensis & 8 & 8 & $\emptyset$ & $\varnothing$ \\
\hline Lb. graminis & 9 & 9 & $\varnothing$ & $\varnothing$ \\
\hline Ln. mesenteroides & 9 & 9 & $\varnothing$ & $\varnothing$ \\
\hline Serratia sp. & 12 & 11 & $\varnothing$ & $\varnothing$ \\
\hline
\end{tabular}

(a) $4{ }^{\circ} \mathrm{C}$ vs. $4-8{ }^{\circ} \mathrm{C}$, (b) $4{ }^{\circ} \mathrm{C}$ vs. $4 / 20-4{ }^{\circ} \mathrm{C}$, (c) $4-8{ }^{\circ} \mathrm{C}$ vs. $4 / 20-8{ }^{\circ} \mathrm{C}$.

- data out of range, $>$ superior value, $\varnothing$ no significant statistical difference.

* Significant statistical difference, $\mathrm{p}$-value $<0.05$.

** High significant statistical difference, $\mathrm{p}$-value $<0.01$.

*** Highly significant statistical difference, $\mathrm{p}$-value $<0.001$. 
mix of the surface product. For the dynamic temperature condition, the same results were observed (Table 3).

In these two cases, some bacterial strains ( $R$. terrigena and $L b$. oligofermentans) were excluded from the results for better readability because they were often under the detection level for the metagenetic analysis (data not shown).

\subsection{Combining $P C A$ results and relative abundance to obtain estimate counts}

Table 4 shows growth parameters, for each strain, calculated from the combination of the PCA counts at $22^{\circ} \mathrm{C}$ and the relative proportions of strains given by metagenetics (estimate abundance results) for constant temperature conditions (at $4{ }^{\circ} \mathrm{C}, 8^{\circ} \mathrm{C}$ and $12{ }^{\circ} \mathrm{C}$ ). Using R software these parameters were obtained by fitting to a primary model of bacterial curves according to the Baranyi equation (Delhalle et al., 2012; Ercolini et al., 2011; Zwietering et al., 1990). These parameters give the bacterial concentration at day 16 (Nmax, log CFU/g), the maximal bacterial growth rate ( $\mu$ max, $1 / \mathrm{h}$ ) and the time to reach the stationary phase (TRSP, days).

These results allowed the bacterial strain subdivision into three classes based on growth parameters for each temperature conditions studied. These three classes are respectively called "dominant", "inhibited"
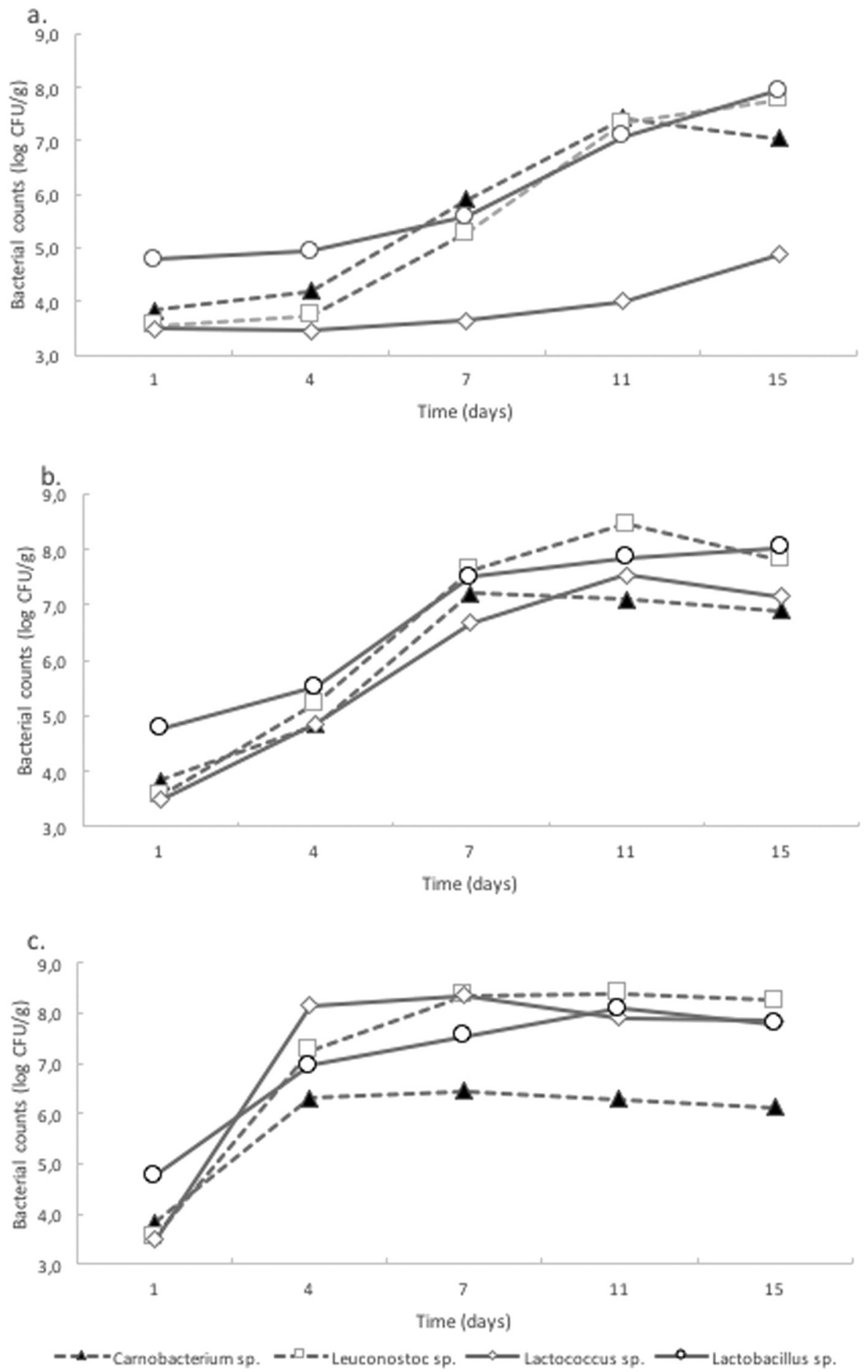

Fig. 2. qPCR counts from inoculated white puddings stored at $4{ }^{\circ} \mathrm{C}(\mathrm{a}), 8{ }^{\circ} \mathrm{C}(\mathrm{b})$ and $12{ }^{\circ} \mathrm{C}(\mathrm{c})$. 
and "subdominant" according to their growth parameters and their behaviour observed inside the bacterial ecosystem:

The "dominant" bacterial species had three high growth parameters: they have the highest growth rate ( $\mu$ max), maximal concentration (Nmax) between 8 and $9 \log$ CFU/g, and rapidly reached the stationary phase during the shelf life of the product.

The "inhibited" bacterial species had a lesser or equal growth rate but they achieved an inferior Nmax value, and stopped their growth at the same time as the "dominant" species.

The "subdominant" bacterial species are all other bacterial species that continued growth when the "dominant" organisms reached the stationary phase, which is the opposite to the "inhibited" bacteria, with a generally lesser growth rate than the "dominant" species. They reached the stationary phase lesser rapidly but they achieved a high maximal concentration.

According to the conditions of storage the bacterial ecosystem change: $\mathrm{C}$. maltaromaticum is the "dominant" bacteria at $4{ }^{\circ} \mathrm{C}$ and $8{ }^{\circ} \mathrm{C}$, while Lc. lactis dominates at $12^{\circ} \mathrm{C}$. Lc. lactis is an "inhibited" and a "subdominant" bacterial species for conditions at $4{ }^{\circ} \mathrm{C}$ and $8{ }^{\circ} \mathrm{C}$ respectively. Lb. graminis is a "subdominant" bacteria at $4{ }^{\circ} \mathrm{C}$ and an "inhibited" species for the two other conditions. Interestingly, Ln. mesenteroides and Lb. fuchuensis were "subdominant" bacteria at all temperatures. On the other hand, Serratia sp. is an "inhibited" bacterium at all temperatures.

Table 5 shows the combination of the PCA counts of the microflora at $22{ }^{\circ} \mathrm{C}$ and the relative proportions of strains obtained by metagenetics (estimate abundance results) for storage conditions with changes of temperature (at $4-8{ }^{\circ} \mathrm{C}, 4 / 20-4{ }^{\circ} \mathrm{C}$ and $4 / 20-8{ }^{\circ} \mathrm{C}$ ). For these situations two parameters were studied: the time necessary to attain a $7 \mathrm{log}$ $\mathrm{CFU} / \mathrm{g}$ threshold of spoilage (days) and the statistical difference between conditions of storage by ANCOVA-tests based on the global growth and the growth rate during exponential phase.

The results of the ANCOVA-tests show that strains have a better bacterial growth at $4-8{ }^{\circ} \mathrm{C}$ than at $4{ }^{\circ} \mathrm{C}$, except for $C$. maltaromaticum that showed a statistically different growth rate only during the exponential phase. Consequently, all species reached the $7 \log \mathrm{CFU} / \mathrm{g}$ threshold earlier at $4-8{ }^{\circ} \mathrm{C}$ than at $4{ }^{\circ} \mathrm{C}$ (Table $5(\mathrm{a})$ ). For the break of $4 \mathrm{~h}$ at $20^{\circ} \mathrm{C}$ during storage this phenomenon was significantly weaker. Indeed, $\mathrm{Ln}$. mesenteroides is the only species which showed a significant statistically effect in the two tested parameters of growth rate. The other strains have a better global growth at $4 / 20-4{ }^{\circ} \mathrm{C}$ (except for $C$. maltaromaticum) and all species reached the $7 \log \mathrm{CFU} / \mathrm{g}$ threshold earlier at $4 / 20-4{ }^{\circ} \mathrm{C}$ than at $4{ }^{\circ} \mathrm{C}$ (Table $5(\mathrm{~b})$ ). Results shows also that there were no significant statistical changes on the growth parameters between the break of $4 \mathrm{~h}$ at $20^{\circ} \mathrm{C}$ and the transition from $4{ }^{\circ} \mathrm{C}$ to $8{ }^{\circ} \mathrm{C}$ but Lc. lactis and Serratia sp. reached the $7 \log \mathrm{CFU} / \mathrm{g}$ earlier (Table 5(c)).

\subsection{Comparison with $q P C R$ results}

Fig. 2 shows the qPCR counts for four genus at $4{ }^{\circ} \mathrm{C}$ (Fig. 2a), $8{ }^{\circ} \mathrm{C}$ (Fig. 2b) and $12{ }^{\circ} \mathrm{C}$ (Fig. 2c). The comparison between metagenetics results and the LAB genus specific qPCR are summarised in Table 6. On

Table 6

Comparison between qPCR and estimate abundance results $\left(\log \mathrm{CFU} \mathrm{g}{ }^{-1}\right)$ for days $1,4,7$, 11 and 15 with ANCOVA-test.

\begin{tabular}{lllll}
\hline & Carnobacterium & Lactobacillus & Lactococcus & Leuconostoc \\
\hline $4{ }^{\circ} \mathrm{C}$ & $\varnothing$ & $\mathrm{qPCR}>$ Meta $^{* *}$ & $\emptyset$ & qPCR $>$ Meta $^{*}$ \\
$8{ }^{\circ} \mathrm{C}$ & $\varnothing$ & $\emptyset$ & $\emptyset$ & $\emptyset$ \\
$12{ }^{\circ} \mathrm{C}$ & $\varnothing$ & $\varnothing$ & $\emptyset$ & $\emptyset$
\end{tabular}

Estimate abundance results: obtained by combination of the PCA counts at $22^{\circ} \mathrm{C}$ and the relative proportions of strains given by metagenetics.

superior value, $\varnothing$ no significant statistical difference.

* Significant statistical difference, p-value $<0.05$.

** Very significant statistical difference, $\mathrm{p}$-value $<0.01$ average, the population overestimation was equal to $1.1 \mathrm{log} \mathrm{CFU} / \mathrm{g}$ in qPCR test at $4{ }^{\circ} \mathrm{C}$ for Lactobacillus and Leuconostoc. Indeed, bacterial curves are convergent except for Lactobacillus and Leuconostoc at $4{ }^{\circ} \mathrm{C}$.

\section{Discussion}

Based on the primary results given on total count on plate agar, the influence of temperature on the development of a whole ecosystem on Belgian white puddings was observed. The power of metagenetic analysis, when added to these basics results, has allowed us to closely follow the evolution of each strain inoculated on the product during its shelf life. In addition, the data have been validated by a qPCR analysis where no significant differences were seen for the quantification of the genera studied except for Lactobacillus and Leuconostoc at $4{ }^{\circ} \mathrm{C}$. These small differences at the beginning of the shelf life can be explained by the detection of DNA from dead bacteria naturally present in large quantities on the raw meat and resulting from microbial destruction during the manufacturing process. This means that the qPCR analysis has detected some DNA fragments from dead organisms that haven't evidently grown on plate agar, leading to a weak overestimation of the qPCR results at the beginning of the experiment. This phenomenon is lesser in metagenetics analysis because of the high variability of strains presents in the product at the beginning of the experiment. Later during the challenge-test, this difference between the two techniques becomes negligible. Indeed, gradually throughout the experiment, the Lactobacillus and Leuconostoc species become a part of the dominant microflora that leads to a dilution effect of the dead bacterial DNA by the living bacteria's DNA.

The large amount of data provided by the combination of the culture-dependent and culture-independent techniques has given useful information about the growth of each strain during challenge tests. Metagenetic analysis also allows for the assessment of the dynamics of bacterial species within a food matrix. It permitted classification of bacterial strains into different categories according to their behaviour in the ecosystem. The so-called "dominant" bacterial species rapidly reached the stationary phase at a concentration of between 8 and $9 \log$ CFU/g while at the same time the "inhibited" strains stopped their growth at a lower concentration. This phenomenon was described by Jameson in 1962 and recently reviewed by other scientists as follows: "the minority population decelerates when the majority or the total population count reaches its maximum" (Ross et al., 2000; Mellefont et al., 2008; Irlinger and Mounier, 2009; Cornu et al., 2011). This Jameson effect was clearly observed in our study, for example at $4{ }^{\circ} \mathrm{C}$ (Table 2), when Lc. lactis and Serratia sp. stopped growth at day 12, at the same time $C$. maltaromaticum reached its maximal concentration and entered its stationary phase. In opposition to this, it can be noticed that in the same condition, the "sub-dominant" organisms continued their growth independently of the "dominant" species behaviour. In this case, the Jameson effect was not illustrated. This pattern is described for all storage conditions with the same strain classifications (Table 2). This phenomenon was also observed by others scientists and they proposed that the growth of the minority population is only partly inhibited after the majority population has reached its stationary phase (Gnanou Besse et al., 2006; Cornu et al., 2011). This can be explained by the fact that the minority population is only partly affected by the limiting resource and/or inhibiting waste product that led it to stop growing (Gnanou Besse et al., 2006; Cornu et al., 2011).

According to this, the bacterial strain subdivision based on growth parameters can be represented as (Table 7):

If $\left(\operatorname{Nmax}_{\text {bacterial strain }}>\operatorname{Nmax}_{\text {others }}\right) \&\left(\mu \max _{\text {bacterial strain }}>\mu\right.$ max $\left.x_{\text {others }}\right)$

$\&\left(\right.$ TRSP $_{\text {bacterial strain }}<$ TRSP $\left._{\text {others }}\right)=$ "dominant" bacterial species.

If $\left(\operatorname{Nmax}_{\text {bacterial strain }} \cong \operatorname{Nmax}_{\text {others }}\right) \&\left(\mu \max _{\text {bacterial strain }} \leq \mu \max _{\text {others }}\right)$ $\&\left(\right.$ TRSP $_{\text {bacterial strain }}>$ TRSP $\left._{\text {others }}\right)=$ "subdominant" bacterial species. 
Table 7

Bacterial strain subdivision based on growth parameters in three categorical classes: D ("dominant"), S ("subdominant"), I ("inhibited”).

\begin{tabular}{|c|c|c|c|c|}
\hline Class & $\mu \max$ & Nmax & TRSP & Growth parameters \\
\hline $\mathrm{D}$ & The highest & Maximal value. Between 8 and $9 \log$ CFU g ${ }^{-1}$ & Rapidly reached & $\begin{array}{l}\text { If }\left(\operatorname{Nmax}_{\text {bacterial strain }}>\operatorname{Nmax}_{\text {others }}\right) \& \\
(\mu \text { max } \\
\left.\text { bacterial strain }>\mu \max _{\text {others }}\right) \& \\
\left(\mathrm{TRSP}_{\text {bacterial strain }}<\mathrm{TRSP}_{\text {others }}\right)\end{array}$ \\
\hline S & Generally lesser & High value & $\begin{array}{l}\text { Continue to growth when the D organisms } \\
\text { reached the stationary phase }\end{array}$ & $\begin{array}{l}\text { If }\left(\operatorname{Nmax}_{\text {bacterial strain }} \cong \operatorname{Nmax}_{\text {others }}\right) \& \\
\left(\mu \text { max }_{\text {bacterial strain }} \leq \mu \max _{\text {others }}\right) \& \\
\left(\mathrm{TRSP}_{\text {bacterial strain }}>\mathrm{TRSP}_{\text {others }}\right)\end{array}$ \\
\hline I & Lesser or equal & Inferior value & The same as the D organisms & $\begin{array}{l}\text { If }\left(\operatorname{Nmax}_{\text {bacterial strain }}<\operatorname{Nmax}_{\text {others }}\right) \& \\
\left(\mu \text { max }_{\text {bacterial strain }} \leq \mu \mathrm{max}_{\text {others }}\right) \& \\
\left(\mathrm{TRSP}_{\text {bacterial strain }}=\mathrm{TRSP}_{\text {others }}\right)\end{array}$ \\
\hline
\end{tabular}

Maximal bacterial growth rate ( $\mu$ max, $1 / \mathrm{h}$ ), bacterial concentration at day 16 (Nmax, log CFU/g) and time to reach the stationary phase (TRSP, days).

If $\left(\mathrm{Nmax}_{\text {bacterial strain }}<\mathrm{Nmax}_{\text {others }}\right) \&\left(\mu \max _{\text {bacterial strain }} \leq \mu \mathrm{max}\right.$
others
$\quad \&\left(\mathrm{TRSP}_{\text {bacterial strain }}=\mathrm{TRSP}_{\text {others }}\right)=$ "inhibited" bacterial species.

Where Nmax (bacterial concentration at day 16, log CFU/g), $\mu$ max (maximal bacterial growth rate, $1 / \mathrm{h}$ ) and TRSP (time to reach the stationary phase, days) are growth parameters.

Regarding the "inhibited" strains, hypotheses can be made about inconvenient growth temperatures ( $\mathrm{T}_{\mathrm{min}}$ ) and/or a microbial competition with the rest of the ecosystem. The composition of white pudding seems not to have an effect on strains competiveness. According to scientific literature, Serratia sp. has a minimum growth temperature $\left(\mathrm{T}_{\min }\right)$ of $0{ }^{\circ} \mathrm{C}$ (Labadie, 1999) and would normally grow at $4{ }^{\circ} \mathrm{C}$. But at this temperature, it is classified as an "inhibited" strain. Therefore, the inhibition of the bacterial growth of Serratia sp. is probably due to an ecosystem effect. Concerning Lactococcus lactis, one study set its $\mathrm{T}_{\min }$ at $10{ }^{\circ} \mathrm{C}$ (Labadie, 1999), while in our experiment a normal growth pattern was observed at $8{ }^{\circ} \mathrm{C}$, allowing its classification in the "sub-dominant" group. In this case, the inhibited development of this organism at $4{ }^{\circ} \mathrm{C}$ is probably due to an ecosystem effect coupled with a temperature effect. Indeed, when Lc. lactis grew at $12{ }^{\circ} \mathrm{C}$, it became the dominant flora and was more competitive than $C$. maltaromaticum which seems to be more adapted to lower temperatures $\left(\mathrm{T}_{\min }\right.$ of $C$. maltaromaticum $=$ $0{ }^{\circ} \mathrm{C}$, (Casaburi et al., 2011)). For Ln. mesenteroides and $\mathrm{Lb}$. fuchensis, for which $\mathrm{T}_{\text {min }}$ are respectively $4{ }^{\circ} \mathrm{C}$ (Osmanagaoglu and Kiran, 2011) and $2{ }^{\circ} \mathrm{C}$ (Zwietering et al., 1993), they stayed "subdominant" for all the temperature conditions tested. The rest of the ecosystem probably does not affect their growth, insofar as they never gained predominance but they were not inhibited either.

The results of the challenge tests with temperature breaks or changes are consistent with our previous observations. Indeed, $C$. maltaromaticum seems to be more adapted to low temperatures. To this end, this bacterium didn't take a great benefit in its growth when the storage temperature moved to $20^{\circ} \mathrm{C}$ for $4 \mathrm{~h}$ (Table 3 ). In contrast, the growth parameters of $L n$. mesenteroides rose during the transition from $4{ }^{\circ} \mathrm{C}$ to $8{ }^{\circ} \mathrm{C}$ or with the break of $4 \mathrm{~h}$ at $20^{\circ} \mathrm{C}$. This is consistent with the fact that its optimal growth temperature $\left(\mathrm{T}_{\mathrm{opt}}\right)$ is between $20{ }^{\circ} \mathrm{C}$ and $35^{\circ} \mathrm{C}$ (Zwietering et al., 1993, Jin et al., 2012). Lc. lactis also has a $\mathrm{T}_{\text {opt }}$ around $25^{\circ} \mathrm{C}$ but any improvement of its growth parameters was not observed. The hypothesis is made that the break time of $4 \mathrm{~h}$ was too short to see a significant effect. In conclusion, a break of $4 \mathrm{~h}$ at $20^{\circ} \mathrm{C}$ is prejudicial only if the storage temperature $\left(4^{\circ} \mathrm{C}\right)$ is respected during the entire life of the product. Moreover it is commonly admitted that the customer's fridge is rarely at $4{ }^{\circ} \mathrm{C}$ (Lagendijk et al., 2010). By taking account of this fact, the lack of respect for good temperature storage $\left(8^{\circ} \mathrm{C}\right.$ instead of $\left.4{ }^{\circ} \mathrm{C}\right)$, particularly in customer's fridges, is more prejudicial than a break of the cold chain for up to $4 \mathrm{~h}$. However, an indication about the true temperature in the product during the $4 \mathrm{~h}$ of breaking time at $20^{\circ} \mathrm{C}$ would be necessary before making this conclusion. Indeed, the internal temperature of white pudding samples may stay colder than $20^{\circ} \mathrm{C}$, due to the thickness of this product, explaining the apparent absence of effect or a weak effect.
In the future, it will be interesting to explore the interactions in the white pudding ecosystem more deeply. Further studies will focus on the comprehension of the mechanisms that force the "inhibited" strains to stop their growth in the early stage of the shelf life of the product. Indeed, it is commonly accepted that the self-limiting growth process in microbial ecosystem is supposed to be due to (i) the exhaustion of one of the essential nutrients, (ii) the accumulation of metabolic waste products which inhibit growth, and/or (iii) the lowering of $\mathrm{pH}$ due to acid production (Cornu et al., 2011). According to the data already obtained, we could suppose that competition for space or nutrient has an effect. The action of a bacteriocin is also not excluded and could for example explain the lack of development of some strains inoculated into the product: $L b$. oligofermentans and $R$. terrigena. It would also be interesting to know the spoilage or biopreservative potential of all the strains inoculated in the Belgian white pudding in this study. Another challenge will be in differentiating the nature of the ecosystem interactions: strain dependent or species dependent. Finally, this supply of new information will be a good start for future experiments when it is considered that the natural contamination of a food product is more complex that an inoculation of eight bacterial strains from different species.

Our applications of the 16S rRNA gene-based pyrosequencing has now extended our view of the dynamic behaviour of complex microbial populations in Belgian white pudding, revealing the quantitative displacement of taxa that occur during microbial successions. By integrating metagenetics with traditional microbiological analysis we have now extended this view of a highly quantitative characterization of dynamic changes that occur during refrigerated storage. In addition to the predictive microbiology, these data also permit to classify the population dynamics into three major classes, based on growth parameters.

\section{Conclusions}

Metagenetic analysis offers a new tool for identifying microorganisms present in perishable foods and for studying their evolution within different environmental conditions. The information that can be obtained provides a clear picture of the microbial community. Microbiological ecology studies have shown that the microbiota of food is much more diverse than the cultivable group of bacteria studied by the use of culture media. The use of these new technologies will open a new era for modelling and predictive microbiology. In this study, these results provide valuable informations for discussing about the theory of the Jameson effect. In addition, it will help food business operators to have a better view of the quality of their product by differentiating between the spoilage or bioprotective microflora. Moreover, it will provide knowledge on the composition and dynamics of white pudding and shown how it is affected by storage temperature. Indeed, many food manufacturers, government agencies, retailers, distribution quality laboratories and researchers use classical culture media without being able to precisely identify the bacterial communities present within the food. In the future, new gold standards for food quality will need to be developed in order to allow the use of metagenetics as a complementary 
technique for characterizing the bacterial flora of products and its use should be considered as a technique for quality control, for accurately determining the length of shelf life and for developing new food products and/or new storage advices.

\section{Acknowledgments}

Our sincere thanks go to Cate Chapman from the Institut Supérieur des Langues Vivantes from the University of Liège (Liège, Belgium) for the support in English editing of the manuscript. The authors also thank the producer who provided the Belgian white pudding samples.

\section{References}

Benson, A.K., David, J.R., Gilbreth, S.E., Smith, G., Nietfeldt, J., Legge, R., Kim, J., Sinha, R., Duncan, C.E., Ma, J., Singh, I., 2014. Microbial successions are assoaciated with chang es in chemical profiles of a model refrigerated fresh pork sausage during an 80-day shelf life study. Appl. Environ. Microbiol. 80, 5178-5194.

Brosius, J., Dull, T.J., Sleeter, D.D., Noller, H.F., 1981. Gene organization and primary structure of a ribosomal RNA operon from Escherichia coli. J. Mol. Biol. 148, 107-127.

Casaburi, A., Nasi, A., Ferrocino, I., Di Monaco, R., Mauriello, G., Villani, F., Ercolini, D., 2011. Spoilage-related activity of Carnobacterium maltaromaticum strains in air-stored and vacuum-packed meat. Appl. Environ. Microbiol. 77, 7382-7393. http://dx.doi.org/10. 1128/AEM.05304-11.

Chaillou, S., Chaulot-Talmon, A., Caekebeke, H., Cardinal, M., Christieans, S., Denis, C., Hélène Desmonts, M., Dousset, X., Feurer, C., Hamon, E., Joffraud, J.-J., La Carbona, S. Leroi, F., Leroy, S., Lorre, S., Macé, S., Pilet, M.-F., Prévost, H., Rivollier, M., Roux, D. Talon, R., Zagorec, M., Champomier-Vergès, M.-C., 2014. Origin and ecological selection of core and food-specific bacterial communities associated with meat and seafood spoilage. ISME J. 1-14 http://dx.doi.org/10.1038/ismej.2014.202.

Cornu, M., Billoir, E., Bergis, H., Beaufort, A., Zuliani, V., 2011. Modeling microbial competition in food: Application to the behavior of Listeria monocytogenes and lactic acid flora in pork meat products. Food Microbiol. 28, 639-647. http://dx.doi.org/10. 1016/j.fm.2010.08.007.

Delcenserie, V., Taminiau, B, Delhalle, L, Nezer, C., Doyen, P. Crevecoeur, S., Roussey, D. Korsak, N., Daube, G., 2014. Microbiota characterization of a Belgian protected designation of origin cheese, Herve cheese, using metagenomic analysis. J. Dairy Sci. 97, 6046-6056. http://dx.doi.org/10.3168/jds.2014-8225.

Delhalle, L., Daube, G., Adolphe, Y., Crevecoeur, S., Clinquart, A., 2012. Les modèles de croissance en microbiologie prévisionnelle pour la maitrise de la sécurité des aliments (synthèse bibliographique). 16 pp. 369-381.

Elizaquível, P., Pérez-Cataluña, A., Yépez, A., Aristimuño, C. Jiménez, E., Cocconcelli, P.S. Vignolo, G., Aznar, R., 2015. Pyrosequencing vs. culture-dependent approaches to analyze lactic acid bacteria associated to chicha, a traditional maize-based fermented beverage from Northwestern Argentina. Int. J. Food Microbiol. 198, 9-18. http://dx. doi.org/10.1016/j.ijfoodmicro.2014.12.027.

Ercolini, D., Ferrocino, I., Nasi, A., Ndagijimana, M., Vernocchi, P., La Storia, A., Laghi, L., Mauriello, G., Guerzoni, M.E., Villani, F., 2011. Monitoring of microbial metabolites and bacterial diversity in beef stored under different packaging conditions. Appl. Environ. Microbiol. 77, 7372-7381. http://dx.doi.org/10.1128/AEM.05521-11.

Esposito, A., Kirschberg, M., 2014. How many 16S-based studies should be included in a metagenomic conference? It may be a matter of etymology. FEMS Microbiol. Lett. 351, 145-146. http://dx.doi.org/10.1111/1574-6968.12375.

European Parliament and Council of the European Union, 2002. Regulation (EC) No 178/ 2002 of the European Parliament and of the Council of 28 January 2002 laying down the general principles and requirements of food law, establishing the European Food Safety Authority and laying down procedures in matters of food safety. Off. J. Eur. Union 338 (326), 331-338.
Food and Agriculture Organization of the United Nations (FAO), 2011A. Global food losses and food waste - extent, causes and prevention. Romanticism.

Galimberti, A., Bruno, A., Mezzasalma, V., De Mattia, F., Bruni, I., Labra, M., 2015. Emerging DNA-based technologies to characterize food ecosystems. Food Res. Int. 69, 424-433. http://dx.doi.org/10.1016/j.foodres.2015.01.017.

Gnanou Besse, N., Audinet, N., Barre, L., Cauquil, A., Cornu, M., Colin, P., 2006. Effect of the inoculum size on Listeria monocytogenes growth in structure media. Int. J. Food Microbiol. 110, 43-51.

Irlinger, F., Mounier, J., 2009. Microbial interactions in cheese: implications for cheese quality and safety. Curr. Opin. Biotechnol. 20, 142-148.

Jin, K.Y., Eom, H.-J., Seo, E.-Y., Lee, D.Y., Kim, J.H., Han, N.S., 2012. Development of a chemically defined minimal medium for the exponential growth of Leuconostoc mesenteroides ATCC8293. J. Microbiol. Biotechnol. 22, 1518-1522.

Kergourlay, G., Taminiau, B., Daube, G., Champomier Vergès, M.-C., 2015. Metagenomic insights into the dynamics of microbial communities in food. Int. J. Food Microbiol. $213,31-39$.

Labadie, J., 1999. Consequences of packaging on bacterial growth. Meat is an ecological niche. Meat Sci. 52, 299-305. http://dx.doi.org/10.1016/S0309-1740(99)00006-6.

Lagendijk, E., Asséré, A., Derens, E., Carpentier, B., 2010. Réfrigération domestique: enquête sur les pratiques des consommateurs et recommandations en matière d' hygiène. 1101 pp. 1-16.

Lipinski, B., Hanson, C., Lomax, J., Kitinoja, L., Waite, R., Searchnger, T., 2013. Reducing food loss and waste. Working Paper, Installmant 2 of Creating a Sustainable Food Future. World Resources Institute, Washington, DC.

Mellefont, L.A., McMeekin, T.A., Ross, T., 2008. Effect of relative inoculum concentration on Listeria monocytogenes growth in co-culture. Int. J. Food Microbiol. 121, 157-168.

Nieminen, T.T., Koskinen, K., Laine, P., Hultman, J., Säde, E., Paulin, L., Paloranta, A., Johansson, P., Björkroth, J., Auvinen, P., 2012. Comparison of microbial communities in marinated and unmarinated broiler meat by metagenomics. Int. J. Food Microbiol. 157, 142-149. http://dx.doi.org/10.1016/j.ijfoodmicro.2012.04.016.

Osmanagaoglu, O., Kiran, F., 2011. Evidence for a chromosomally determined mesenterocin, a bacteriocin produced by Leuconostoc mesenteroides subsp. mesenteroides OZ. J. Basic Microbiol. 51, 279-288. http://dx.doi.org/10.1002/jobm. 201000240

Pothakos, V., Taminiau, B., Huys, G., Nezer, C., Daube, G., Devlieghere, F., 2014. Psychrotrophic lactic acid bacteria associated with production batch recalls and sporadic cases of early spoilage in Belgium between 2010 and 2014. Int. J. Food Microbiol. 191C, 157-163. http://dx.doi.org/10.1016/j.ijfoodmicro.2014.09.013.

Remenant, B., Jaffrès, E., Dousset, X., Pilet, M., Zagorec, M., 2015. Bacterial spoilers of food: Behavior, fi tness and functional properties. Food Microbiol. 45, 45-53.

Riquelme, C., Câmara, S., Enes Dapkevicius, M.D.L.N., Vinuesa, P., da Silva, C.C.G., Malcata, F.X., Rego, O.a., 2015. Characterization of the bacterial biodiversity in Pico cheese (an artisanal Azorean food). Int. J. Food Microbiol. 192, 86-94. http://dx.doi.org/10.1016/ j.ijfoodmicro.2014.09.031.

Ross, T., Dalgaard, P., Tienungoon, S., 2000. Predictive modelling of the growth and survival of Listeria in fishery products. Int. J. Food Microbiol. 62, 231-245.

Schloss, P.D., Westcott, S.L., Ryabin, T., Hall, J.R., Hartmann, M., Hollister, E.B., Lesniewski, R.a., Oakley, B.B., Parks, D.H., Robinson, C.J., Sahl, J.W., Stres, B., Thallinger, G.G., Van Horn, D.J., Weber, C.F., 2009. Introducing mothur: open-source, platform-independent, community-supported software for describing and comparing microbial communities. Appl. Environ. Microbiol. 75, 7537-7541. http://dx.doi.org/10.1128/AEM. 01541-09.

Wang, Y., Qian, P.Y., 2009. Conservative fragments in bacterial 16S rRNA genes and primer design for $16 \mathrm{~S}$ ribosomal DNA amplicons in metagenomic studies. PLoS One 4. http://dx.doi.org/10.1371/journal.pone.0007401.

Zwietering, M.H., Jongenburger, I., Rombouts, F.M., Van't Riet, K., 1990. Modeling of the bacterial growth curve. Appl. Environ. Microbiol. 56, 1875-1881.

Zwietering, M.H., Wijtzes, T., Rombouts, F.M., Van't Riet, K., 1993. A decision support system for prediction of microbial spoilage in foods. J. Ind. Microbiol. 12, 324-329. 